\title{
United States fights to protect its semiconductor industry...
}

\section{Washington}

TrADE reprisals against Japan could be announced by the United States within the week in the wake of US frustration at alleged Japanese trade malpractice.

The new measures have been expected after US opposition to the attempted purchase by a Japanese company of the US semiconductor group Fairchild Semiconductor Corporation.

The plan by Fujitsu Limited to buy Fairchild apparently foundered after members of the Reagan administration - notably Commerce Secretary Malcolm Baldrige - expressed their opposition to the takeover. The antagonism toward the Fujitsu deal is symbolic of growing frustration in the United States over Japanese trade practices

From the US government's perspective, the Fujitsu deal underlined the weakness of the US industry, and reinforced concern about national security with a vital product increasingly controlled by a foreign company. For US industry, the deal was also evidence that Japanese predatory marketing practices - selling semiconductors for less than their cost - was damaging US companies, and making them easy takeover targets.

But Fairchild officials do not see things that way. Fairchild president Donald Brooks said the deal would bave added strength to the domestic industry, provided jobs and brought more sales of US- made chips in Japan.

By the end of last week, Fairchild announced it had received several offers of help for a leveraged buyout from its parent company Schlumberger Limited, under the terms of which ownership of Fairchild would have passed to its management. The company still plans to form links with Fujitsu including joint technology development, shared foundry manufacturing and licence exchanges.

Bad timing may have been critical for the Fujitsu-Fairchild takeover. The United States has promised to take action against Japan if violations of a semiconductor trade agreement signed last summer do not stop. That agreement required Iapan to stop selling chips below cost on international markets and to open its market to foreign semiconductor sales.

The US industry now claims that Japanese companies have never complicd with that agreement. The US government apparently agrees with that assessment and has promised to take some action by 1 April. Action could take the form of duties that would bring the cost of Japanese chips into line with those of chips manufactured in the United States.

But Michael Borrus. of the University of California, says scotching the Fairchild deal and imposing duty docs not solve the real problem plaguing the US semiconductor industry. Borrus says Japanese companies have becr quietly acquiring

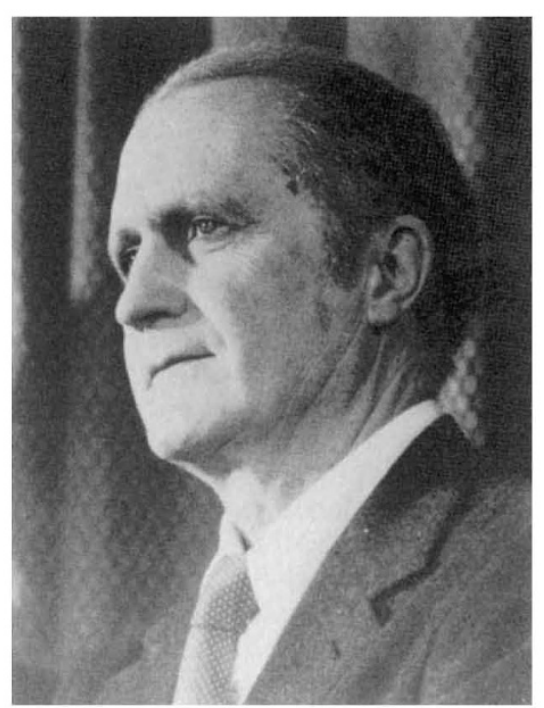

US Commerce Secretary Malcolm Baldrige worries about 'national interest'.

small smart US high-technology companies. This has provided extremely strong prospects for the future, siphoning US technological skill into Japanese industry. Borrus says the Fujitsu deal might have collapsed on its own because of market conditions, but in any case it serves to divert attention from the other more serious issue.

A spokesman for Baldrige says a cabinet-level group is being formed to see if steps need to be taken to protect US companies from foreign takeovers "not in the national interest". But Borrus does not believe that the government is yet taking the problem seriously enough.

Joseph Palca

\section{....and Japan fights to}

Tokyo

AN ATrkMPr to Jimit foreign participation in a Japanese telecommunications consortium has raised strong protests from the British and US governments and threatens to ignite another trade dispute. At stake is a plan by Britain's Cable and Wireless to lay a network of optical fibrecables linking Western Europe, the United States and the Far East.

Two consortia have made plans to offer alternative services to Kokusai Denshin Denwa (KDD) which at present monopolizes Japan's international telecommunications market. One consortium, International Digital Communications Planning Co. (IDC), is 20 per cent owned by Cable and Wireless and proposes to lay its own trans-Pacific submarine cable to link with a Cable and Wireless network that will span North America and the Atlantic Ocean. The other consortium, International Telecom Japan (ITJ), is allJapanese and intends to lease circuits on Intelsat satellites and a trans-Pacific cable to be laid in 1988 by KDD and American

\section{protect telecommunications}

Telephone and Telegraph.

The Ministry of Post and Telecommunications opposed the IDC plan from the outset. First it was argued that the market is too small for three companies. But even KDD forecasts a tripling in Japan's international telecommunications market to Y 600,000 million by 1995 . Then a foreign say in international telecommunications was objected to on grounds of 'national security'.

Now Fumio Watanabe of the Federation of Economic Organizations (Keidanren), with the blessing of the Post and Telecommunications Ministry, has proposed a merger of ITJ and IDC that would slash Cable and Wireless's share to 3 per cent, while key Japanese member companies could take 5 per cent.

With a large number of Japanese shareholder companies in common between IDC and ITJ, there have been no objections from the Japanese side. But Britain and the United States are protesting.

The British Prime Minister, Mrs Margaret Thatcher, in a letter to Japan's
Prime Minister, Mr Yasuhiro Nakasone, says the Japanese moves run "counter to the commitments made by your government about further opening of the Japanese market". And US Trade Representative Clayton Yeutter and Commerce Secretary Malcolm Baldrige have also lodged strong protests with the Japanese government because the US companies Pacific Telesis International and Merrill Lynch are members of the IDC consortium and its cable would land in Alaska.

Jonathan Solomon, Cable and Wireless's director in charge of planning, who arrived in Tokyo last week, protested at the merger proposal, saying 'it doesn't make any business sense to invest 3 per cent", and he also urged Watanabe to commit the new group to laying a transPacific cable. But Watanabe says the cable is a matter for the Japanese government to decide and although "Japan is preparing to make its telecommunications market more open, .... the market cannot be opened until we are ready".

David Swinbanks 